\title{
Taxonomic study of sucrose-positive Aeromonas jandaei-like isolates from faeces, water and eels: emendation of $A$. jandaei Carnahan et al. 1992
}

\author{
Consuelo Esteve, ${ }^{1}$ Lázara Valera, ${ }^{1}$ Carmen Gutiérrez² \\ and Antonio Ventosa ${ }^{2}$ \\ ${ }^{1}$ Departamento de Microbiología y Ecología, Facultad de Biología, Universitat de València, \\ E-46100 Burjassot (Valencia), Spain \\ 2Departamento de Microbiología y Parasitología, Facultad de Farmacia, Universidad de Sevilla, \\ E-41012 Sevilla, Spain
}

Correspondence

Consuelo Esteve estevem@uv.es

Fourteen sucrose-positive Aeromonas jandaei-like isolates from fresh water and reared European eels were subjected to a polyphasic study to determine their taxonomic position. Numerical taxonomy was used to analyse phenotypic data obtained for these isolates and 43 type and reference strains representative of recognized Aeromonas species. The $A$. jandaei cluster (phenon 1) was defined at $81.6 \%$ similarity $\left(S_{\jmath}\right)$; this included the $A$. jandaei-like isolates, the sucrose-positive strain Aeromonas veronii biogroup sobria CECT 4910 and nearly all $A$. jandaei reference strains used in the study. Four other reference strains of $A$. veronii biogroup sobria and the type strain of Aeromonas ichthiosmia were peripheral to the $A$. jandaei cluster. The supra-group ' $A$. jandaei-A.veronii biogroup sobria-A. ichthiosmia' was linked at $80 \cdot 7 \%$ similarity $\left(S_{\mathrm{J}}\right)$ and was clearly segregated from the phenotypic core of the $A$. veronii biogroup sobria species, which was related to the reference strain Popoff 224 (CECT 4835). DNA relatedness between strains grouped in the $A$. jandaei cluster (phenon 1) and $A$. jandaei CECT $4228^{\top}$ ranged from 70 to $100 \%$, but was below $50 \%$ when DNAs from $A$. veronii biogroup sobria CECT 4835, $A$. veronii biogroup veronii CECT $4257^{\top}$ and $A$. ichthiosmia CECT $4486^{\top}$ were used. In addition, DNA relatedness between peripheral $A$. veronii biogroup sobria strains and the species $A$. jandaei (CECT $4228^{\top}$ ), A. veronii (CECT $4257^{\top}$, CECT 4835) and $A$. ichthiosmia (CECT $4486^{\top}$ ) was always below $54 \%$, as it was between the species $A$. ichthiosmia (CECT $4486^{\top}$ ) and $A$. veronii (CECT $4257^{\top}$, CECT 4835). Emendation of $A$. jandaei is proposed; this taxon now includes sucrose-positive clinical and environmental strains as well as environmental isolates that are pathogenic for fish and humans. Other new traits for this species are the ability to grow at $4-42^{\circ} \mathrm{C}$, acid production from glycerol but not from lactose, D-melibiose or D-raffinose, the use of D-gluconate, L-glutamate or L-proline but not L-lactate, L-alanine, L-arabinose or L-arginine, hydrolytic activity against casein, elastin, starch and lecithin and the inability to lyse arbutin. The DNA $\mathrm{G}+\mathrm{C}$ content of $A$. jandaei is also reported for the first time; it ranges from $58 \cdot 1$ to $61 \cdot 1 \mathrm{~mol} \%$. On the other hand, the DNA relatedness data support the classification of peripheral reference strains of $A$. veronii biogroup sobria outside this taxon, indicating that biogroup sobria requires further revision.

\section{INTRODUCTION}

During the last 15 years, at least seven novel Aeromonas species have been isolated from clinical samples, including the taxa Aeromonas veronii and Aeromonas jandaei (Hickman-Brenner et al., 1987, 1988; Schubert et al., 1990a, b; Carnahan et al., 1991a, b; Martínez-Murcía et al., 1992b). These two species show $99.5 \%$ similarity in their complete 1502 bp 16S rDNA sequences (Martínez-Murcía et al., 1992a), but they can clearly be segregated by DNA-DNA hybridization methods (Carnahan et al., 1991a). In fact, the

Published online ahead of print on 7 March 2003 as DOI 10.1099/ijs.0.02504-0.

Abbreviation: DHG, DNA homology group.

Details of the strains used in this study, $\mathrm{LD}_{50}$ values of $A$. jandaei-like strains and a dendrogram based on the $S_{S M} / U P G M A$ analysis are available as supplementary material in IJSEM Online. 
species $A$. veronii and A. jandaei are synonyms of DNA homology groups (DHG) 8/10 and 9, respectively, of the genus Aeromonas (Joseph \& Carnahan, 2000).

The present taxonomic status of $A$. veronii is based mainly on genomic data (Hickman-Brenner et al., 1987; MartínezMurcía et al., 1992a), since its biogroups veronii and sobria are not phenotypically related (Kämpfer \& Altwegg, 1992; Valera \& Esteve, 2002). In fact, A. veronii biogroup sobria displays closer phenotypic resemblance to A. jandaei, as phenotypic differentiation between these taxa is based only on acid production from sucrose, which is positive for A. veronii biogroup sobria but negative for $A$. jandaei (Carnahan et al., 1991c; Abbot et al., 1992). On the other hand, the limits of $A$. veronii biogroup sobria have recently been extended by the inclusion of the type strain of Aeromonas ichthiosmia (Huys et al., 2001).

Although A. jandaei was formerly associated with clinical samples, the reported incidence of this taxon in human disease is extremely low (Janda et al., 1994; Bravo et al., 1995; Hänninen et al., 1995; Kühn et al., 1997; Borrell et al., 1998; Ghenghesh et al., 1999; Demarta et al., 2000). By contrast, presumptive $A$. jandaei strains have frequently been isolated from cultured eels suffering from 'red fin disease' (Esteve et al., 1993; Valera \& Esteve, 2002). However, these environmental strains were somewhat related to A. veronii biogroup sobria, as they produced acid from sucrose. The aim of the present study was to determine the taxonomic position of these novel isolates in relation to reference strains representative of recognized Aeromonas species (A. jandaei, A. veronii, Aeromonas sobria, A ichthiosmia, Aeromonas enteropelogenes, Aeromonas trota, Aeromonas allosaccharophila and Aeromonas popoffii).

\section{METHODS}

Aeromonas strains and culture conditions. The 14 sucrosepositive A. jandaei-like isolates recovered from fresh water and eels are detailed in Supplementary Table A (available in IJSEM Online). These environmental isolates were resistant to the following antimicrobials ( $\mathrm{mg} \mathrm{l}^{-1}$ unless indicated): ampicillin (50), penicillin $\mathrm{V}(10)$, sulfanilamide (300), sulfadimethoxine (12) and trimethoprim (25); but they were sensitive to tetracycline (15), tobramycin (25), streptomycin (25), gentamicin (10), rifampin (30), amikacin (25), kanamycin (50), erythromycin (15), chloramphenicol (25), nitrofurantoin (10), nalidixic acid (50), oxolinic acid (10) and polymyxin B (300 UI $1^{-1}$ ) (Esteve, 1995). These strains, which were mainly associated with epizootic outbreaks that occurred in eel farms from 1987 to 1998 , were stored long-term as freeze-dried cultures. The 43 reference strains used in the study are detailed in Supplementary Table B (available in IJSEM Online). Strains were grown overnight on tryptone water $[1 \%(\mathrm{w} / \mathrm{v})$ tryptone, $0.5 \%(\mathrm{w} / \mathrm{v}) \mathrm{NaCl}$ in distilled water; $\mathrm{pH} 7 \cdot 2$ ] or tryptone soy agar (Oxoid) at $28{ }^{\circ} \mathrm{C}$.

Phenotypic characterization and numerical taxonomy. Each strain (57 strains and six duplicate cultures) was examined for 121 physiological and biochemical traits, as described previously (Valera \& Esteve, 2002). Production of $\beta$-haemolysins against human erythrocytes was tested on solid medium according to Esteve (1995). The tests results were scored as 1 for positive responses and 0 for negative responses; these data were examined with the NTSYS-pc numerical taxonomy and multivariance analysis system (Rolhf, 1998). Similarities were calculated using both simple matching $\left(S_{\mathrm{SM}}\right)$ and Jaccard $\left(S_{\mathrm{J}}\right)$ coefficients; clustering was achieved by the UPGMA method and cophenetic correlation was calculated using the correlation coefficient $r$ (Sneath \& Sokal, 1973). Test error was calculated according to Sneath \& Johnson (1972).

DNA base composition. Previously described procedures (Marmur, 1961; Johnson, 1994) were used to extract and purify DNAs from 29 Aeromonas strains (Table 1). The DNA G+C content of the strains was obtained from the midpoints $\left(T_{\mathrm{m}}\right)$ of the thermal denaturation profiles (Marmur \& Doty, 1962; Ferragut \& Leclerc, 1976; Owen \& Hill, 1979). The $T_{\mathrm{m}}$ of DNA from Escherichia coli NCTC $9001^{\mathrm{T}}$ was determined experimentally and was used as a reference.

DNA-DNA hybridization. We have used the competitive nitrocellulose filter method, which is a classical method to test DNA relatedness among bacterial strains (Johnson, 1994). DNAs from reference strains (CECT $4228^{\mathrm{T}}$, CECT $4486^{\mathrm{T}}$, CECT $4257^{\mathrm{T}}$ and CECT 4835) were denatured and then bound to a nitrocellulose filter or labelled with $\left[{ }^{3} \mathrm{H}\right] \mathrm{dCTP}$ (Amersham). Each hybridization mixture included the following: (i) filter containing unlabelled reference singlestranded (ss) DNA, (ii) labelled homologous ssDNA, (iii) unlabelled competitor ssDNA and (iv) $30 \%$ formamide (Sigma). The ratio of the concentrations of labelled homologous ssDNA and unlabelled competitor ssDNA was equal to or less than $1: 150$. DNA-DNA hybridizations were made at a reassociation temperature of $55 \cdot 5-56 \cdot 0{ }^{\circ} \mathrm{C}$, depending on the values of DNA $T_{\mathrm{m}}$. All hybridization experiments were performed in triplicate. In some cases, the results showed in Table 1 are values of DNA relatedness obtained from two different hybridization experiments. Percentage relatedness was calculated as described previously (Johnson, 1994). In addition, the SD was calculated for each hybridization experiment according to Sokal \& Rohlf (1969).

Pathogenicity. Animal models were used to assess potential pathogenicity of A. jandaei DHG9 strains. Juvenile European eels (5-12 g) and 6-week-old mice (19-31 g) were used in the infection trials. For each strain, six animals were anaesthetized and challenged with the same bacterial dose $\left(10^{8}, 10^{7}, 10^{6}, 10^{5}, 10^{4}\right.$ or $10^{3}$ cells). Six animals injected with sterile PBS were used as a negative control. Mortalities in a 7 day period were only considered if the injected bacterium was reisolated as a pure culture from freshly dead animals. The $\mathrm{LD}_{50}$ of bacterial cells was calculated for each strain (Reed \& Müench, 1938).

\section{RESULTS AND DISCUSSION}

\section{Phenotypic characterization and numerical taxonomy}

We have used results obtained from duplicate cultures to calculate the test error, which is a methodological parameter. Thus, the mean probability $(P)$ of an erroneous result for the biochemical tests was $0.9 \%\left(S_{\mathrm{n}}^{2}=0.0097\right)$, which is an acceptable value according to Sneath \& Johnson (1972). Consistent results were obtained from the phenotypic study, as nearly the same dendrogram was derived by the use of the two similarity coefficients $\left(S_{\mathrm{SM}}\right.$ and $\left.S_{\mathrm{J}}\right)$ and UPGMA clustering algorithm. In this study, $S_{\mathrm{J}} /$ UPGMA analysis was chosen because the correlation observed between the similarity matrix and the corresponding tree matrix $(r=0 \cdot 90)$ was higher than that presented for $S_{\mathrm{SM}} /$ UPGMA analysis $(r=0 \cdot 86)$. Seventy-seven per cent of strains were grouped by the $S_{\mathrm{J}} /$ UPGMA analysis into nine 
Table 1. DNA base composition of $A$. jandaei strains and other Aeromonas strains and DNA-DNA relatedness among isolates

DNA-DNA relatedness percentages were obtained from hybridization experiments performed in triplicate. ND, Not determined.

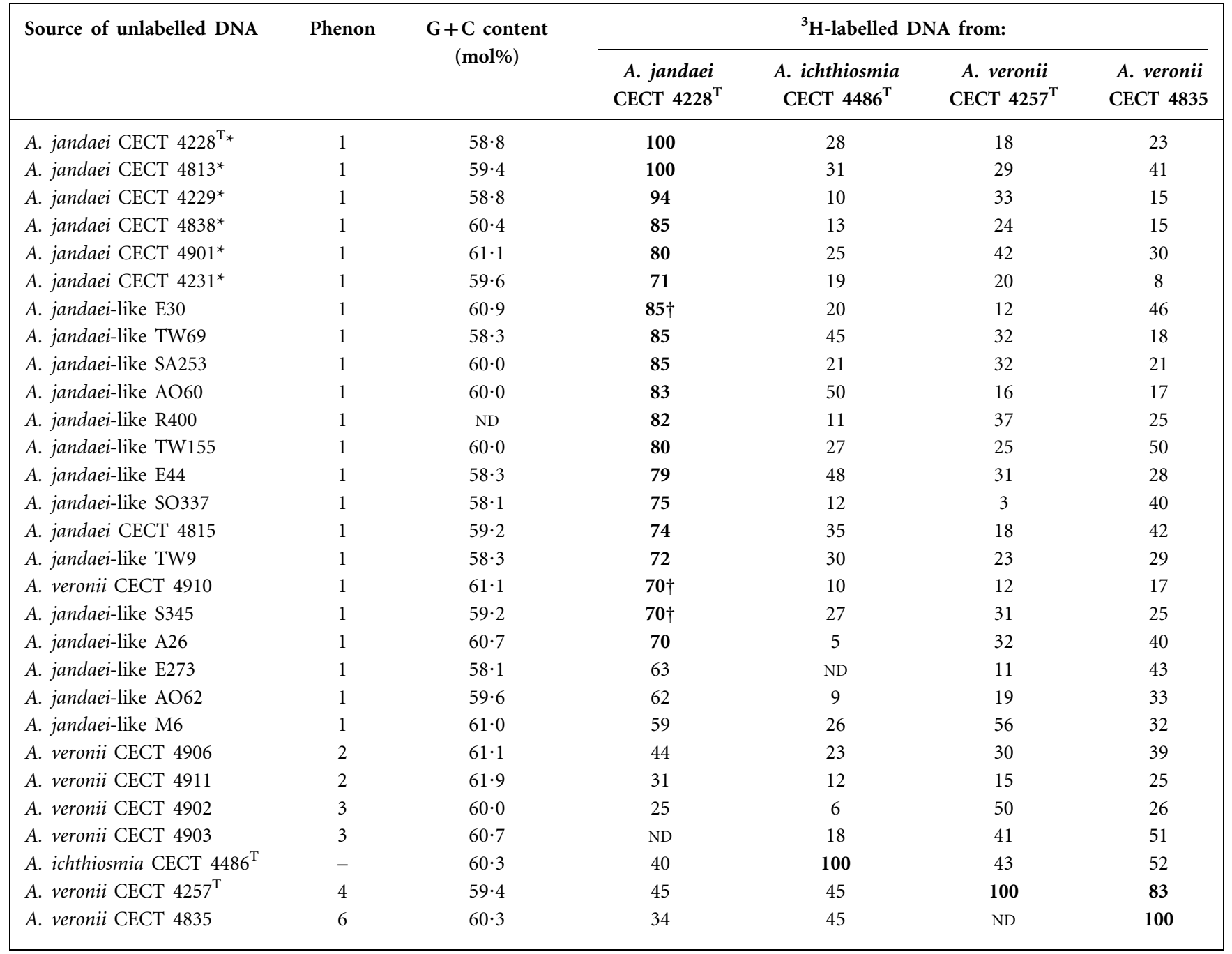

*Strain included in the original description of A. jandaei (Carnahan et al., 1991a).

$\dagger$ Reciprocal hybridizations yielded values of DNA relatedness in the range $75-87 \%$.

phenons defined at or above $81 \cdot 6 \%$ similarity (Fig. 1). The $S_{\mathrm{SM}}$ /UPGMA analysis yielded almost identical grouping at similarity values of $\geqslant 90 \%$, although the percentage of total clustered strains was slightly higher (81\%). A dendrogram based on the $S_{\mathrm{SM}} / \mathrm{UPGMA}$ analysis is shown in Supplementary Fig. A, available in IJSEM Online.

Phenon 1 , which is formed at $81.6 \%$ similarity $\left(S_{\mathrm{J}}\right)$, was identified as $A$. jandaei. This cluster included the strain A. veronii biogroup sobria CECT 4910 , the 14 A. jandaei-like isolates and all reference strains of the species $A$. jandae $i$ with the exception of CECT 4814, which was clustered in the 'A. trota cluster' (phenon 9). The phenotypic characteristics of the 'A. jandaei cluster' (phenon 1) showed discrepancies from the description of this species (Carnahan et al., 1991a) regarding the high percentages of sucrose- and elastase-positive strains observed (Table 2). In contrast to data reported previously (Hasan et al., 1992), all A. jandaei strains displayed elastolytic activity on the medium of Hsu et al. (1981). In our opinion, this medium might enhance the elastolytic capability of strains as it contains large amounts of ground elastin $(1 \%, \mathrm{w} / \mathrm{v})$ but very small amounts of tryptone $(0 \cdot 2 \%, \mathrm{w} / \mathrm{v})$ and it also contains micronutrients (L-cysteine and $\mathrm{Ca}^{2+}$ ions) that stabilize elastase structure and function. Moreover, the $\mathrm{pH}$ of the medium is buffered to $8 \cdot 0$, which is optimal for most reported elastases (Wretlind \& Wadström, 1977; Kothary \& Kreger, 1985).

Four reference strains of $A$. veronii biogroup sobria (29\% of the total strains of this taxon), which were clustered in phenons 2 and 3, and the type strain of A. ichthiosmia were close to the 'A. jandaei cluster' (Fig. 1). This supra-group, 'A. jandaei-A.veronii biogroup sobria-A. ichthiosmia', was 


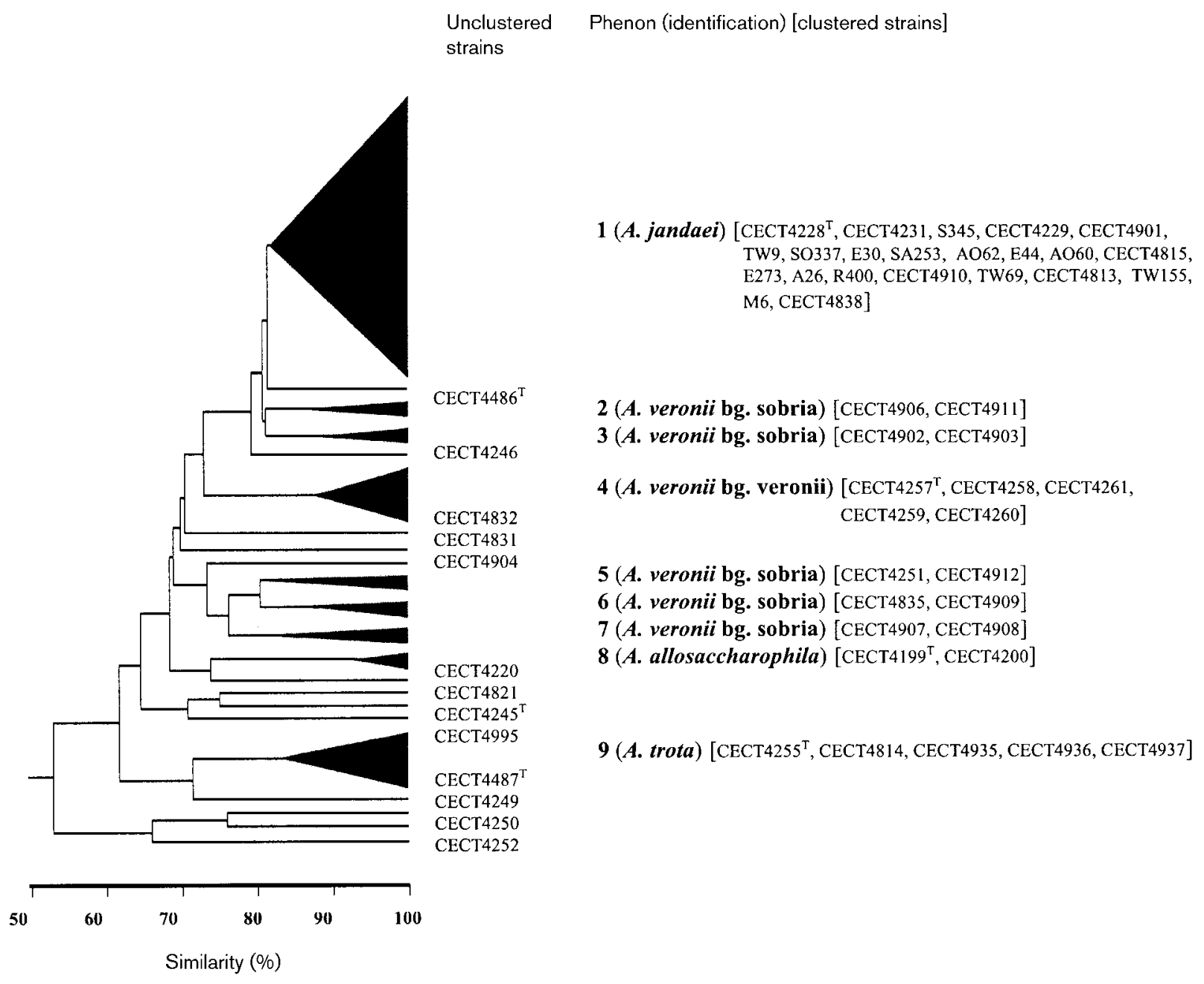

Fig. 1. Simplified dendrogram based on the $S_{\text {J }}$ coefficient and UPGMA clustering algorithm, showing the relationship between the nine phenons defined at or above $81.6 \%$ similarity. bg., Biogroup. A dendrogram based on the $S_{\mathrm{SM}} / \mathrm{UPGMA}$ analysis is available in IJSEM Online.

linked at $80 \cdot 7 \%$ similarity $\left(S_{\mathrm{J}}\right)$ and was clearly segregated from the other Aeromonas species (Fig. 1). In fact, we have observed that the phenotypic core of the species A. veronii biogroup sobria corresponded to phenons 5,6 and 7 (Fig. 1). These clusters grouped $36 \%$ of the total A. veronii biogroup sobria strains, among them strain Popoff 224 (CECT 4835), which is a reference strain for the genospecies DHG8 (Joseph \& Carnahan, 2000). Our results are in agreement with the previous numerical study by Kämpfer \& Altwegg (1992), in which these reference strains of A. veronii biogroup sobria were grouped in two well-segregated clusters. Thus, diversity inside the taxon A. veronii biogroup sobria could be much higher than is currently recognized (Abbot et al., 1992; Martinetti Lucchini \& Altwegg, 1992; Huys et al., 2001). In view of these overall results, for the genomic study, we used all strains that clustered in the supra-group 'A. jandaei-A.veronii biogroup sobria-A. ichthiosmia' (Fig. 1) as well as the reference strains of A. veronii (biogroup veronii CECT $4257^{\mathrm{T}}$; biogroup sobria CECT 4835).

As expected, the two biogroups of $A$. veronii were not related phenotypically, as all reference strains of $A$. veronii biogroup veronii were clustered in phenon 4 (Fig. 1). Moreover, our numerical analysis clearly segregated the species $A$. allosaccharophila (phenon 8 ) from the $A$. veronii taxon, in contrast to other studies (Huys et al., 1996, 2001). Finally, we should note that all reference strains of the species $A$. trota were clustered in phenon 9, along with strain CECT 4814 (Fig. 1), which had been received as a reference strain for A. jandaei.

\section{Genomic study: DNA base composition and DNA-DNA relatedness}

The DNA $\mathrm{G}+\mathrm{C}$ contents of strains included in the ' $A$. jandaei cluster' (phenon 1) ranged from $58 \cdot 1$ to $61 \cdot 1 \mathrm{~mol} \%$ 
Table 2. Variable characteristics of $A$. jandaei and their distribution depending on strain origin

Clinical strains tested were CECT 4228 ${ }^{\mathrm{T}}$, CECT 4229, CECT 4813, CECT 4815, CECT 4838, CECT 4901 and CECT 4910. Environmental strains tested were CECT 4231, TW9, A26, E30, E44, AO60, TW69, TW155, SA253, SO337, S345 and R400. LDC, Lysine decarboxylase (Moeller's medium).

\begin{tabular}{|c|c|c|c|c|}
\hline \multirow[t]{2}{*}{ Characteristic } & \multicolumn{2}{|c|}{ Phenotype $^{*}$} & \multirow{2}{*}{$\begin{array}{c}\text { Positive } \\
\text { strains (\%) }\end{array}$} & \multirow{2}{*}{$\begin{array}{c}\text { Reaction of strain } \\
\text { CECT } 4228^{T}\end{array}$} \\
\hline & Clinical & Environmental & & \\
\hline LDC & $9 / 10 \dagger$ & $10 / 12$ & 86 & + \\
\hline Growth at $\mathrm{pH} 4 \cdot 5$ & $2 / 7$ & $4 / 12$ & 32 & - \\
\hline \multicolumn{5}{|c|}{ Acid production from: } \\
\hline Sucrose & $1 / 10 \dagger$ & $11 / 12$ & $55 \ddagger$ & - \\
\hline D-Cellobiose & $0 / 10 \dagger$ & $3 / 12$ & 14 & - \\
\hline Maltose & $6 / 7$ & $11 / 12$ & 90 & + \\
\hline \multicolumn{5}{|l|}{ Hydrolysis of: } \\
\hline SDS & $3 / 7$ & $9 / 12$ & 63 & + \\
\hline Elastin & $7 / 10 \dagger$ & $10 / 12$ & $77 \ddagger$ & $+\ddagger$ \\
\hline Tween 80 & $5 / 7$ & $5 / 12$ & 53 & + \\
\hline \multicolumn{5}{|l|}{ Utilization of: } \\
\hline Acetate & $6 / 7$ & $9 / 12$ & 79 & + \\
\hline DL-Glycerate & $1 / 7$ & $3 / 12$ & 21 & - \\
\hline Citrate & $9 / 10 \dagger$ & $10 / 12$ & 86 & + \\
\hline L-Histidine & $2 / 7$ & $6 / 12$ & 42 & - \\
\hline L-Serine & $7 / 7$ & $10 / 12$ & 90 & + \\
\hline D-Glucosamine & $5 / 7$ & $12 / 12$ & 90 & - \\
\hline \multicolumn{5}{|l|}{ Virulence for:\$ } \\
\hline Eels & $0 / 2$ & $4 / 8$ & 40 & - \\
\hline Mice & $4 / 5 \|$ & $4 / 8$ & 62 & + \\
\hline
\end{tabular}

${ }^{\star}$ No. positive/no. tested.

$\dagger$ Results reported by Carnahan et al. (1991a) for strains AS-206, AS-235 and AS-176 are also included.

¥Reported elsewhere as negative (Carnahan et al., 1991a; Hasan et al., 1992).

$\S$ Strains that exhibited an $\mathrm{LD}_{50}$ of less than $10^{7 \cdot 5}$ c.f.u.

IIReported by Janda \& Kokka (1991) for clinical A. jandaei strains.

(Table 1). This range of three units is similar to that described among bacterial strains belonging to a single Aeromonas species (Popoff et al., 1981; Hickman-Brenner et al., 1987; Esteve et al., 1995b). The DNA G + C contents of strains clustered in phenons 2 and 3 were respectively within the ranges $61 \cdot 1-61 \cdot 9 \mathrm{~mol} \%$ and $60 \cdot 0-60 \cdot 7 \mathrm{~mol} \%$ (Table 1). It is noteworthy that the DNA G $+\mathrm{C}$ contents of all these strains are being reported for the first time, even those of strains included in the original description of the species A. jandaei (Carnahan et al., 1991a). As expected, the overall values obtained for DNA G $+\mathrm{C}$ content (Table 1) were within the range reported for the genus Aeromonas (57·0-63 mol\%) (Popoff et al., 1981; Popoff, 1984; Allen et al., 1983; Hickman-Brenner et al., 1987; Schubert \& Hegazi, 1988; Schubert et al., 1990a, b; Esteve et al., 1995a, b; Huys et al., 1997).

Except for isolates E273, AO62 and M6, DNA relatedness among strains grouped in the ' $A$. jandaei cluster' (phenon 1) and the type strain, A. jandaei CECT $4228^{\mathrm{T}}$, ranged from 70 to $100 \%$ (Table 1 ), values currently accepted for the definition of a bacterial species (Stackebrandt \& Goebel, 1994). In addition, reciprocal DNA-DNA hybridizations performed between some strains clustered in phenon 1 (E30, CECT 4910 and S345) and the type strain, CECT $4228^{\mathrm{T}}$, yielded values in the range $75-87 \%$. Thus, these strains, which include many sucrose-positive $A$. jandaei-like isolates and the clinical strain CECT 4910, should be classified as members of genospecies 9 (DHG9), and they therefore belong to the $A$. jandaei taxon. As expected, DNA relatedness between $A$. jandaei DHG9 strains and representative strains of $A$. ichthiosmia (CECT $4486^{\mathrm{T}}$ ) and $A$. veronii (CECT $4257^{\mathrm{T}}$, CECT 4835) was well under $70 \%$ (Table 1 ). Thus, DNA-DNA hybridizations clearly segregated A. jandaei DHG9 from the taxa A. ichthiosmia and A. veronii, although they are close relatives on the basis of $16 \mathrm{~S}$ rDNA sequence comparison (Martínez-Murcía et al., 1992a; Collins et al., 1993) and phenotypic features (Fig. 1).

Reciprocal DNA-DNA hybridizations performed between A. ichthiosmia CECT $4486^{\mathrm{T}}$ and reference strains of $A$. veronii (biogroup veronii $\mathrm{CECT} 4257^{\mathrm{T}}$; biogroup sobria 
CECT 4835) yielded values of around $45 \%$ DNA relatedness (Table 1). In fact, our data agree with the value of $60 \%$ DNA relatedness originally reported for the pair A. ichthiosmia CECT $4486^{\mathrm{T}}$ /A. veronii CECT 4835 (Schubert et al., 1990b) by using the spectrophotometric method (De Ley et al., 1970). In contrast, they contradict the value of $96 \%$ DNA relatedness recently reported for the pair A. ichthiosmia CECT $4486^{\mathrm{T}}$ /A. veronii CECT $4257^{\mathrm{T}}$ (Huys et al., 2001) by using the micro-well hybridization method of Goris et al. (1998). It is worth noting that Huys et al. (2001) used these DNA relatedness data to propose that $A$. ichthiosmia is a later synonym of $A$. veronii. However, in our opinion, this proposal should be reconsidered on the basis of the striking lack of concordance between these hybridization studies (Huys et al., 2001; Schubert et al., 1990b; Table 1).

On the other hand, the peripheral A. veronii biogroup sobria strains (phenons 2 and 3 ) were related to the species A. jandaei, A. ichthiosmia and A. veronii at levels of DNA relatedness below $50 \%$ (Table 1 ), and they therefore do not belong to any of these taxa. It is worth noting that DNA relatedness between strains CECT 4902, CECT 4903, CECT 4906 and CECT 4911 and A. veronii (CECT $4257^{\mathrm{T}}$, CECT 4835 ) is reported here for the first time (Table 1), even though these four strains have been widely used as reference strains for A. veronii biogroup sobria DHG8 (Huys et al., 1996, 2001). However, according to our results, these four strains should not be assigned to the species A. veronii, indicating that the biogroup sobria is a heterogeneous taxon that requires further revision. In fact, strain CECT 4911 has recently been classified as A. allosaccharophila on the basis of gyrB gene sequencing data (Yáñez et al., 2003).

The genomic relationship between the reference strains of $A$. veronii biogroup sobria DHG8 (CECT 4835) and A. veronii biogroup veronii DHG10 (CECT $4257^{\mathrm{T}}$ ) was closer (Table 1) than the current limit for species definition $(70 \%)$ and our data are therefore in agreement with previous reports that classified them in the A. veronii taxon (Hickman-Brenner et al., 1987; Martínez-Murcía et al., 1992a; Yáñez et al., 2003).

The overall SD of DNA relatedness determined in our competitive hybridization study, at around $6 \%$, is comparable to other studies based on the micro-well (Goris et al., 1998; Christensen et al., 2000) and spectrophotometric methods (Angen et al., 1999). Moreover, we have observed that the mean SD of high DNA similarity data $(\geqslant 70 \%)$ was around $2 \%$, this value being significantly below the $7 \%$ recorded as the mean SD for low DNA similarity data $(<70 \%)$.

In summary, the present phenotypic and genotypic data support the classification of the A. jandaei-like strains, as well as strain CECT 4910, previously assigned to A. veronii biogroup sobria, in the species $A$. jandaei. Thus, we propose the emendation of the species $A$. jandaei to include these novel clinical and environmental isolates.

\section{Phenotypic differentiation of the species A. jandaei}

A. jandaei can be differentiated easily from the species A. veronii biogroup veronii, Aeromonas hydrophila, Aeromonas bestiarum, Aeromonas eucrenophila and Aeromonas encheleia by the absence of production of acid from salicin and its inability to hydrolyse aesculin and arbutin. In addition, $A$. jandaei can be segregated from Aeromonas caviae and Aeromonas media by its production of gas from glucose and its positive response to VogesProskauer and gluconate oxidation tests. A. jandaei and Aeromonas schubertii can be separated on the basis of the negative responses displayed by the latter for the production of indole, acid from D-mannitol and gas from glucose. The key reactions that differentiate $A$. jandaei from phenotypically related species and reference strains of mesophilic Aeromonas species are detailed in Table 3. It is worth noting that Aeromonas culicicola and A. jandaei cannot be differentiated on the basis of the phenotypic profile reported recently by Pidiyar et al. (2002).

\section{Prevalence and pathogenicity of $\boldsymbol{A}$. jandaei}

The fact that the species $A$. jandaei includes sucrose-positive strains may be highly significant in establishing the prevalence of this taxon in clinical samples, as similar sucrose-positive Aeromonas isolates from human sources have until now been largely identified as $A$. veronii biogroup sobria (Carnahan et al., 1991c; Abbott et al., 1992). In fact, the present study has demonstrated clearly that one of these previously identified $A$. veronii biogroup sobria isolates, CECT 4910, is a bona fide A. jandaei strain. Thus, such misidentifications could account for the scanty reports on A. jandaei in relation to human infectious diseases (Janda \& Abbott, 1998). Moreover, the prevalence of A. jandaei in aquatic environments (fresh water and fish) is reported for the first time, as only one environmental strain, CECT 4231, has so far been isolated, from a prawn (Carnahan et al., 1991a). It is worth noting that environmental A. jandaei strains present $\mathrm{LD}_{50}$ values for mice similar to those reported for clinical $A$. jandaei strains (Supplementary Table A), and they can therefore be classified into the 'high' ( $\mathrm{LD}_{50}<10^{7 \cdot 0}$ c.f.u.) or 'moderate' $\left(\mathrm{LD}_{50} 10^{7 \cdot 0}-10^{7 \cdot 5}\right.$ c.f.u.) virulence categories described previously by Janda \& Kokka (1991). Furthermore, nearly all A. jandaei strains have been able to degrade elastin, elastolytic activity currently being related to pathogenic significance in Aeromonas (Hsu et al., 1981). Thus, the clinical significance of the species $A$. jandaei and its importance in public health issues need to be reviewed in the light of the present findings.

\section{Emended description of Aeromonas jandaei Carnahan et al. 1992}

Gram-negative, straight rods that are motile by a single polar flagellum. Colonies develop within $24 \mathrm{~h}$ at $28^{\circ} \mathrm{C}$ on TSA (Oxoid) and are not pigmented. No brown water-soluble pigment is produced. Growth occurs on MacConkey agar 
Table 3. Key tests for phenotypic differentiation of $A$. jandaei

Species: 1, A. jandaei (strains TW9, A26, E30, E44, AO60, TW69, TW155, SA253, SO337, S345, R400 and CECT strains $4228^{\mathrm{T}}$, 4229, 4231, 4813, 4815, 4838, 4901 and 4910); 2, Aeromonas sp. (CECT strains 4902, 4903, 4906 and 4911); 3, A. ichthiosmia; 4, A. veronii biogroup veronii; 5 , A. veronii biogroup sobria (CECT strains 4251, 4835, 4907-4909 and 4912); 6, A. allosaccharophila; 7, A. trota; 8, A. enteropelogenes; 9, A. popoffii; 10, A. sobria. Data were taken from this study; Valera \& Esteve (2002) and Kämpfer \& Altwegg (1992). Percentages of positive strains are indicated as: ,$+ 100-86 \%$; V +, 85-80\%; -, 14-0\%; numbers indicate other percentages.

\begin{tabular}{|c|c|c|c|c|c|c|c|c|c|c|}
\hline Characteristic & 1 & 2 & 3 & 4 & 5 & 6 & 7 & 8 & 9 & 10 \\
\hline \multicolumn{11}{|c|}{ Acid production from: } \\
\hline Salicin & - & - & - & + & - & - & - & - & - & - \\
\hline L-Arabinose & - & 25 & - & - & 33 & 67 & - & - & - & - \\
\hline D-Cellobiose & $-*$ & + & - & 80 & 67 & + & + & + & - & + \\
\hline Voges-Proskauer & + & + & + & + & $-\dagger$ & - & - & - & + & + \\
\hline LDC & $+^{*}$ & + & - & + & 33 & + & + & + & - & + \\
\hline Growth at $42^{\circ} \mathrm{C}$ & + & - & $+\dagger$ & 80 & - & + & 60 & + & - & - \\
\hline \multicolumn{11}{|l|}{ Hydrolysis of: } \\
\hline Arbutin & - & - & - & + & - & - & - & - & - & - \\
\hline SDS & 63 & 50 & - & + & - & - & + & + & + & + \\
\hline \multicolumn{11}{|l|}{ Use of: } \\
\hline L-Lactate & - & - & - & - & - & - & + & - & $-\dagger$ & - \\
\hline Acetate & $\mathrm{v}+$ & 50 & + & + & - & + & + & + & - & - \\
\hline Citrate & $+^{*}$ & + & - & 80 & 50 & 67 & + & + & + & + \\
\hline L-Glutamate & + & + & + & + & + & + & + & + & + & - \\
\hline D-Gluconate & + & + & + & + & + & + & + & + & + & - \\
\hline L-Alanine & - & - & - & 40 & - & - & + & + & $-\dagger$ & - \\
\hline L-Arginine & - & - & - & - & - & + & $\mathrm{V}+$ & - & - & - \\
\hline L-Proline & + & + & + & + & + & + & + & + & - & - \\
\hline Glycine & - & - & - & - & - & - & + & - & - & - \\
\hline L-Arabinose & - & - & - & - & - & + & - & - & - & - \\
\hline
\end{tabular}

${ }^{\star}$ Results reported by Carnahan et al. (1991a) for strains AS-206, AS235 and AS-176 are also included.

$\dagger$ Different response reported elsewhere (Schubert et al., 1990b; Huys et al., 1997, 2001).

and on TCBS agar (Oxoid). Chemo-organotrophic, with both oxidative and fermentative metabolism. Acid and gas are produced from glucose. Kovacs' cytochrome oxidaseand catalase-positive. Reduces nitrate to nitrite. Does not swarm on solid media $(1.5 \%$ agar, $\mathrm{w} / \mathrm{v})$ and is resistant to vibriostatic agent $\mathrm{O} / 129(150 \mu \mathrm{g})$. Growth occurs in the presence of $0-3 \%(\mathrm{w} / \mathrm{v}) \mathrm{NaCl}$, at temperatures between 4 and $42{ }^{\circ} \mathrm{C}$ and under alkaline $(\mathrm{pH} 8 \cdot 5)$ conditions. All strains produce $\mathrm{H}_{2} \mathrm{~S}$ from L-cysteine. Positive for indole, Moeller's arginine dihydrolase, Thornley's arginine, gluconate oxidation and Voges-Proskauer test but negative for Moeller's ornithine and glutamine decarboxylases. All strains produce acid from fructose, D-galactose, glycerol, D-mannose, D-mannitol, D-ribose and D-trehalose. None of the strains produces acid from adonitol, D-amygdalin,
D-arabinose, L-arabinose, arbutin, dulcitol, 2-deoxy-Dglucose, myo-inositol, lactose, D-melibiose, D-raffinose, Drhamnose, salicin, D-sorbitol, L-sorbose, xylitol or xylose. All strains use the following substrates as sole carbon and energy sources: $\mathrm{N}$-acetylglucosamine, fumarate, Dgluconate, L-glutamate, L-glutamine, malate (alkalinization), L-proline and succinate. None of the strains uses transaconitate, adenine, L-alanine, $\gamma$-aminobutyrate, L-arabinose, L-arginine, L-asparagine, L-aspartate, benzoate, L-carnosine, L-citrulline, L-cysteine, D-galacturonate, D-glucuronate, glutarate, glutathione, glycine, guanine, L-isoleucine, Llactate, L-leucine, L-lysine, maleate (alkalinization), malonate (alkalinization), L-methionine, mucate, L-ornithine, L-phenylalanine, propionate, putrescine, sarcosine, Ltartrate, L-threonine, L-tryptophan, L-tyrosine, L-valine or xanthine. Strains hydrolyse casein and gelatin but not alginate, arbutin or aesculin. All strains display amylase and lecithinase activities and excrete $\beta$-haemolysins against human red blood cells. All strains are resistant to ampicillin and penicillin but sensitive to amikacin, gentamicin, tetracycline and tobramycin (Carnahan et al., 1991a; Esteve 1995). Additional characteristics that vary among strains are shown in Table 2 . The DNA G $+\mathrm{C}$ content ranges from $58 \cdot 1$ to $61 \cdot 1 \mathrm{~mol} \%$, as determined by the $T_{\mathrm{m}}$ method.

Isolated from clinical samples, fresh water, prawns and eels (Anguilla anguilla). Mostly virulent for eels and mice; the latter animal model is currently used to assess pathogenic significance for humans.

The type strain is ATCC $49568^{\mathrm{T}}\left(=\right.$ CECT $\left.4228^{\mathrm{T}}\right)$; it presents all of the properties given above for the species. In addition, it is positive for Moeller's lysine decarboxylase, produces acid from maltose, hydrolyses elastin, SDS and Tween 80 and uses acetate, citrate and L-serine (Table 2). However, it is negative for acid production from sucrose and Dcellobiose, does not grow at $\mathrm{pH} 4 \cdot 5$ and does not use DLglycerate, L-histidine or D-glucosamine. Isolated from faeces. The DNA G+C content of the type strain is $58 \cdot 8 \mathrm{~mol} \%$.

\section{ACKNOWLEDGEMENTS}

This study was supported by project PETRI PTR 1995-0577-OP from the Spanish Ministerio de Ciencia y Tecnología.

\section{REFERENCES}

Abbot, S. L., Cheung, W. K. W., Kroske-Bystrom, S., Malekzadeh, T. \& Janda, J. M. (1992). Identification of Aeromonas strains to the genospecies level in the clinical laboratory. J Clin Microbiol 30, 12621266.

Allen, D. A., Austin, B. \& Colwell, R. R. (1983). Aeromonas media, a new species isolated from river water. Int J Syst Bacteriol 33, 599-604.

Angen, Ø., Mutters, R., Caugant, D. A., Olsen, J. E. \& Bisgaard, M. (1999). Taxonomic relationships of the [Pasteurella] haemolytica complex as evaluated by DNA-DNA hybridizations and 16S rRNA sequencing with proposal of Mannheimia haemolytica gen. nov., comb. nov., Mannheimia granulomatis comb. nov., Mannheimia 
glucosida sp. nov., Mannheimia ruminalis sp. nov. and Mannheimia varigena sp. nov. Int J Syst Bacteriol 49, 67-86.

Borrell, N., Figueras, M. J. \& Guarro, J. (1998). Phenotypic identification of Aeromonas genomospecies from clinical and environmental sources. Can J Microbiol 44, 103-108.

Bravo, L., Monte, R. J., Alfonso, V., Cabrera, N., Gómez, M., Hernández, R. \& García, B. (1995). New species of Aeromonas isolated in Cuba. Rev Cubana Med Trop 47, 215-216 (in Spanish).

Carnahan, A., Fanning, G. R. \& Joseph, S. W. (1991a). Aeromonas jandaei (formerly genospecies DNA group 9 A. sobria), a new sucrose-negative species isolated from clinical specimens. J Clin Microbiol 29, 560-564.

Carnahan, A. M., Chakraborty, T., Fanning, G. R., Verma, D., Ali, A., Janda, J. M. \& Joseph, S. W. (1991b). Aeromonas trota sp. nov., an ampicillin-susceptible species isolated from clinical specimens. J Clin Microbiol 29, 1206-1210.

Carnahan, A. M., Behram, S. \& Joseph, S. W. (1991c). Aerokey II: a flexible key for identifying clinical Aeromonas species. J Clin Microbiol 29, 2843-2849.

Christensen, H., Angen, Ø., Mutters, R., Olsen, J. E. \& Bisgaard, M. (2000). DNA-DNA hybridization determined in micro-wells using covalent attachment of DNA. Int J Syst Evol Microbiol 50, 1095-1102.

Collins, M. D., Martinez-Murcia, A. J. \& Cai, J. (1993). Aeromonas enteropelogenes and Aeromonas ichthiosmia are identical to Aeromonas trota and Aeromonas veronii, respectively, as revealed by small-subunit rRNA sequence analysis. Int J Syst Bacteriol 43, 855-856.

De Ley, J., Cattoir, H. \& Reynaerts, A. (1970). The quantitative measurement of DNA hybridization from renaturation rates. Eur $J$ Biochem 12, 133-142.

Demarta, A., Tonolla, M., Caminada, A., Beretta, M. \& Peduzzi, R. (2000). Epidemiological relationships between Aeromonas strains isolated from symptomatic children and household environments as determined by ribotyping. Eur J Epidemiol 16, 447-453.

Esteve, C. (1995). Numerical taxonomy of Aeromonadaceae and Vibrionaceae associated with reared fish and surrounding fresh and brackish water. Syst Appl Microbiol 18, 391-402.

Esteve, C., Biosca, E. G. \& Amaro, C. (1993). Virulence of Aeromonas hydrophila and some other bacteria isolated from European eels Anguilla anguilla reared in freshwater. Dis Aquat Org 16, 15-20.

Esteve, C., Gutiérrez, M. C. \& Ventosa, A. (1995a). DNA relatedness among Aeromonas allosaccharophila strains and DNA hybridization groups of the genus Aeromonas. Int J Syst Bacteriol 45, 390-391.

Esteve, C., Gutiérrez, M. C. \& Ventosa, A. (1995b). Aeromonas encheleia sp. nov., isolated from European eels. Int J Syst Bacteriol 45, 462-466.

Ferragut, C. \& Leclerc, H. (1976). Étude comparative des méthodes de détermination du $T_{\mathrm{m}}$ de l'ADN bactérien. Ann Microbiol 127, 223-235.

Ghenghesh, K. S., Bara, F., Bukris, B., el-Surmani, A. \& Abeid, S. S. (1999). Characterization of virulence factors of Aeromonas isolated from children with and without diarrhoea in Tripoli, Libya. J Diarrhoeal Dis Res 17, 75-80.

Goris, J., Suzuki, K., De Vos, P., Nakase, T. \& Kersters, K. (1998). Evaluation of a microplate DNA-DNA hybridization method compared with the initial renaturation method. Can J Microbiol 44, 1148-1153.

Hänninen, M.-L., Salmi, S., Mattila, L., Taipalinen, R. \& Siitonen, A. (1995). Association of Aeromonas spp. with travellers' diarrhoea in Finland. J Med Microbiol 42, 26-31.
Hasan, J. A. K., Macaluso, P., Carnahan, A. M. \& Joseph, S. W. (1992). Elastolytic activity among Aeromonas spp. using a modified bilayer plate assay. Diagn Microbiol Infect Dis 15, 201-206.

Hickman-Brenner, F. W., MacDonald, K. L., Steigerwalt, A. G., Fanning, G. R., Brenner, D. J. \& Farmer, J. J., III (1987). Aeromonas veronii, a new ornithine decarboxylase-positive species that may cause diarrhea. J Clin Microbiol 25, 900-906.

Hickman-Brenner, F. W., Fanning, G. R., Arduino, M. J., Brenner, D. J. \& Farmer, J. J., III (1988). Aeromonas schubertii, a new mannitolnegative species found in human clinical specimens. J Clin Microbiol 26, 1561-1564.

Hsu, T. C., Waltman, W. D. \& Shotts, E. B. (1981). Correlation of extracellular enzymatic activity and biochemical characteristics with regard to virulence of Aeromonas hydrophila. Dev Biol Stand 49, 101-111.

Huys, G., Coopman, R., Janssen, P. \& Kersters, K. (1996). Highresolution genotypic analysis of the genus Aeromonas by AFLP fingerprinting. Int J Syst Bacteriol 46, 572-580.

Huys, G., Kämpfer, P., Altwegg, M. \& 7 other authors (1997). Aeromonas popoffii sp. nov., a mesophilic bacterium isolated from drinking water production plants and reservoirs. Int J Syst Bacteriol 47, 1165-1171.

Huys, G., Kämpfer, P. \& Swings, J. (2001). New DNA-DNA hybridization and phenotypic data on the species Aeromonas ichthiosmia and Aeromonas allosaccharophila: A. ichthiosmia Schubert et al. 1990 is a later synonym of A. veronii HickmanBrenner et al. 1987. Syst Appl Microbiol 24, 177-182.

Janda, J. M. \& Abbott, S. L. (1998). Evolving concepts regarding the genus Aeromonas: an expanding panorama of species, disease presentations, and unanswered questions. Clin Infect Dis 27, $332-344$.

Janda, J. M. \& Kokka, R. P. (1991). The pathogenicity of Aeromonas strains relative to genospecies and phenospecies identification. FEMS Microbiol Lett 90, 29-34.

Janda, J. M., Guthertz, L. S., Kokka, R. P. \& Shimada, T. (1994). Aeromonas species in septicemia: laboratory characteristics and clinical observations. Clin Infect Dis 19, 77-83.

Johnson, J. L. (1994). Similarity analysis of DNAs. In Methods for General and Molecular Bacteriology. pp. 655-682. Edited by P. Gerhardt, R. G. E. Murray, W. A. Wood \& N. R. Krieg. Washington, DC: American Society for Microbiology.

Joseph, S. W. \& Carnahan, A. M. (2000). Update of the genus Aeromonas. ASM News 66, 218-223.

Kämpfer, P. \& Altwegg, M. (1992). Numerical classification and identification of Aeromonas genospecies. J Appl Bacteriol 72, 341-351.

Kothary, M. H. \& Kreger, A. S. (1985). Production and partial characterization of an elastolytic protease of Vibrio vulnificus. Infect Immun 50, 534-540.

Kühn, l., Albert, M. J., Ansaruzzaman, M. \& 8 other authors (1997). Characterization of Aeromonas spp. isolated from humans with diarrhea, from healthy controls, and from surface water in Bangladesh. J Clin Microbiol 35, 369-373.

Marmur, J. (1961). A procedure for the isolation of deoxyribonucleic acid from microorganisms. J Mol Biol 3, 208-218.

Marmur, J. \& Doty, P. (1962). Determination of the base composition of deoxyribonucleic acid from its thermal denaturation temperature. J Mol Biol 5, 109-118.

Martinetti Lucchini, G. \& Altwegg, M. (1992). rRNA gene restriction patterns as taxonomic tools for the genus Aeromonas. Int $J$ Syst Bacteriol 42, 384-389. 
Martínez-Murcía, A. J., Benlloch, S. \& Collins, M. D. (1992a). Phylogenetic interrelationships of members of the genera Aeromonas and Plesiomonas as determined by $16 \mathrm{~S}$ ribosomal DNA sequencing: lack of congruence with results of DNA-DNA hybridizations. Int $J$ Syst Bacteriol 42, 412-421.

Martínez-Murcía, A. J., Esteve, C., Garay, E. \& Collins, M. D. (1992b). Aeromonas allosaccharophila sp. nov., a new mesophilic member of the genus Aeromonas. FEMS Microbiol Lett 91, 199-206.

Owen, R. J. \& Hill, L. R. (1979). The estimation of base composition, base pairing and genome size of bacterial deoxyribonucleic acids. In Identification Methods for Microbiologists, 2nd edn, pp. 217298. Edited by F. A. Skinner \& D. W. Lovelock. London: Academic Press.

Pidiyar, V., Kaznowski, A., Narayan, N. B., Patole, M. \& Shouche, Y. S. (2002). Aeromonas culicicola sp. nov., from the midgut of Culex quinquefasciatus. Int J Syst Evol Microbiol 52, 1723-1728.

Popoff, M. (1984). Genus III. Aeromonas Kluyver and Van Niel 1936, $398^{\mathrm{AL}}$. In Bergey's Manual of Systematic Bacteriology, vol. 1, pp. 545-548. Edited by N. R. Krieg \& J. G. Holt. Baltimore: Williams \& Wilkins.

Popoff, M. Y., Coynault, C., Kiredjian, M. \& Lemelin, M. (1981). Polynucleotide sequence relatedness among motile Aeromonas species. Cur Microbiol 5, 109-114.

Reed, M. J. \& Müench, M. (1938). A simple method for estimating fifty percent endpoints. Am J Hyg 27, 493-497.

Rolhf, F. J. (1998). NTSYS-pc. Numerical Taxonomy and Multivariant Analysis System, version 2.0. New York: Exeter Software.

Schubert, R. H. W. \& Hegazi, M. (1988). Aeromonas eucrenophila species nova Aeromonas caviae a later and illegitimate synonym of Aeromonas punctata. Zentbl Bakteriol Mikrobiol Hyg A 268, 3439.

Schubert, R. H. W., Hegazi, M. \& Wahlig, W. (1990a). Aeromonas enteropelogenes species nova. Hyg Med 15, 471-472.

Schubert, R. H. W., Hegazi, M. \& Wahlig, W. (1990b). Aeromonas ichthiosmia species nova. Hyg Med 15, 477-479.

Sneath, P. H. A. \& Johnson, R. (1972). The influence on numerical taxonomic similarities of errors in microbiological tests. $J$ Gen Microbiol 72, 377-392.

Sneath, P. H. A. \& Sokal, R. R. (1973). Numerical Taxonomy. The Principles and Practice of Numerical Classification. Edited by D. Kennedy \& R. B. Park. San Francisco: W. B. Freeman.

Sokal, R. R. \& Rohlf, F. J. (1969). Biometry, the Principles and Practice of Statistics in Biological Research. Ames, IA: Iowa State University Press.

Stackebrandt, E. \& Goebel, B. M. (1994). Taxonomic note: a place for DNA-DNA reassociation and 16S rRNA sequence analysis in the present species definition in bacteriology. Int J Syst Bacteriol 44, 846-849.

Valera, L. \& Esteve, C. (2002). Phenotypic study by numerical taxonomy of strains belonging to the genus Aeromonas. J Appl Microbiol 93, 77-95.

Wretlind, B. \& Wadström, T. (1977). Purification and properties of a protease with elastase activity from Pseudomonas aeruginosa. J Gen Microbiol 103, 319-327.

Yáñez, M. A., Catalán, V., Apráiz, D., Figueras, M. J. \& MartínezMurcia, A. J. (2003). Phylogenetic analysis of members of the genus Aeromonas based on gyrB gene sequences. Int J Syst Evol Microbiol 53, 875-883. 